\title{
Studies on the Effect of Integrated Nutrient Management (INM) on Growth and Yield Parameters of Carrot (Daucas carota L.) cv. Kuroda Improved under Southern Telangana Conditions
}

\author{
V. Shanu ${ }^{1}$, D. Lakshminarayana ${ }^{2}$, P. Prasanth ${ }^{2}$ and D. Saida Naik ${ }^{3}$ \\ ${ }^{1}$ Department of Vegetable Science, ${ }^{2}$ Department of Floriculture and Landscaping, \\ College of Horticulture, Mojerla, SKLTS Horticultural University, Rajendranagar, \\ Hyderabad - 500032, India \\ ${ }^{3}$ Department of Crop Physiology, College of Agriculture, PJTS Agricultural University, \\ Rajendranagar, Hyderabad - 500032, India \\ *Corresponding author
}

\section{Keywords}

Carrot cv. Kuroda improved, INM, Growth, Yield

Article Info

Accepted:

20 March 2019

Available Online:

10 April 2019
A B S T R A C T

A field experiment was conducted during rabi 2017-2018 at Vegetable Research Block, College of Horticulture - Mojerla, SKLTS Horticultural University, Hyderabad, Telangana, India, to study the effect of integrated nutrient management (INM) on growth and yield parameters of carrot (Daucas carota L.) cv. Kuroda improved. The experiment was carried out with the nine integrated nutrient management treatments i.e. $\mathrm{T}_{1}-\mathrm{RDF}$ (NPK @ 50:40:50 kg/ha), T - FYM 12 t/ha, T $T_{3}$ - Vermicompost @ $6 \mathrm{t} / \mathrm{ha}_{2} \mathrm{~T}_{4-}-$ Rhizosphere Bacteria (AZB + PSB each @ $7 \mathrm{~kg} / \mathrm{ha}$ ), $\mathrm{T}_{5}-50 \% \mathrm{RDF}+50 \% \mathrm{FYM} @ 6$ $\mathrm{t} / \mathrm{ha}, \mathrm{T}_{6}-50 \% \mathrm{RDF}+50 \%$ Vermicompost @ $3 \mathrm{t} / \mathrm{ha}, \mathrm{T}_{7}-50 \% \mathrm{RDF}+50 \%$ Rhizosphere Bacteria, $\mathrm{T}_{8}-25 \% \mathrm{RDF}+50 \% \mathrm{FYM} @ 6 \mathrm{t} / \mathrm{ha}+50 \%$ Vermicompost @ $3 \mathrm{t} / \mathrm{ha}, \mathrm{T}_{9}-25 \%$ RDF+50\% FYM @6 t/ha +50\% Vermicompost@3t/ha + 50\% Rhizosphere Bacteria, in Randomized Block Design and replicated thrice. Among the treatments, $\mathrm{T}_{9}$ (25\% RDF +50\%FYM@6 t/ha +50\% Vermicompost@3t/ha + 50\% Rhizosphere Bacteria) registered significantly higher plant height $(53.50 \mathrm{~cm})$, more number of leaves per plant (16.40), maximum leaf length $(38.20 \mathrm{~cm})$ and fresh weight of leaves $(62.46 \mathrm{~g})$, least number of days taken to harvest (75.33 days), maximum root length $(19.76 \mathrm{~cm})$, root diameter $(3.96 \mathrm{~cm})$, fresh weight of root $(81.33 \mathrm{~g})$, root yield per plot $(5.60 \mathrm{~kg})$ and root yield per hectare $(18.60 \mathrm{t})$.

\section{Introduction}

Carrot (Daucus carota L.) is an important root vegetable, belongs to the family umbelliferae with diploid chromosome number $2 \mathrm{n}=18$. It is cultivated all over the world, during spring-summer in temperate countries and winter in tropical and subtropical countries. Carrot is an excellent source of carotene a precursor of vitamin A and fibre in the diet (Handelman, 2001). It also contains abundant amounts of nutrients 
such as protein, carbohydrates, fibre and sodium (Ahmad et al., 2004). Carrot fleshy roots are used as a vegetable for salads, soups and are also steamed or boiled in other vegetable dishes (Amjad et al., 2005). Besides the food value it has, different parts of carrot can be used for different medicinal purposes due to a wide range of reported pharmacological effects (Rossi et al., 2007). Carrot is a heavy feeder of nutrients, which removes $100 \mathrm{~kg} \mathrm{~N}, 50 \mathrm{~kg} \mathrm{P}_{2} \mathrm{O}_{5}$ and $180 \mathrm{~kg}$ $\mathrm{K}_{2} \mathrm{O}$ per hectare and is very sensitive to nutrient and soil moisture (Sunanda Rani and MallaReddy, 2007). Nowadays Chemical fertilizers are the main source of nutrients used for carrot cropping. However, continuous dependence on chemical fertilizers causes nutritional imbalance and adverse effects on physico-chemical and biological properties of the soil. Integrated nutrient management (INM) is a better approach for supplying nutrition to the crop by including organic and inorganic sources of nutrients. Thus a combined use of organic manures, biofertilizers with a reduced dose of chemical fertilizers, not only pave the way for higher yield and quality produce but also help to maintain the soil health and reduce pollution problems. Keeping the facts in view, the present investigation was planned to find out the effect of integrated nutrient management on growth and yield parameters of carrot under Southern Telangana conditions.

\section{Materials and Methods}

The present investigation was conducted to study the effect of integrated nutrient management (INM) on growth and yield of carrot (Daucas carota L.) cv. Kuroda improved under Southern Telangana conditions at Vegetable Research Block, College of Horticulture - Mojerla, SKLTS Horticultural University, Hyderabad (Telangana) situated at 780 29' East longitude and $17019^{\prime}$ North latitude with an altitude of
$542.3 \mathrm{~m}$ above the mean sea level. The location is characterized by semi arid climate. The carrot variety Kuroda improved used as experimental material and experiment was laid out in a randomized block design with nine treatments having three replications. The soil of the experimental site was sandy loam having soil $\mathrm{pH} 6.5$, organic carbon $0.27 \%$ and available $\mathrm{N}, \mathrm{P}$ and $\mathrm{K}$ content of 206, 26.00 and $220 \mathrm{~kg}$ ha- 1 respectively. The total nine treatments consist of $\mathrm{T}_{1}-\mathrm{RDF}$ (NPK @ 50:40:50 kg/ha), T T $_{2}$ FYM 12 t/ha, T T $_{3}$ Vermicompost @6t/ha, T4- Rhizosphere Bacteria (AZB + PSB each @ 7 kg/ha), T 5 -50 $\% \mathrm{RDF}+50 \% \mathrm{FYM} @ 6 \mathrm{t} / \mathrm{ha}, \mathrm{T}_{6}-50 \%$ $\mathrm{RDF}+50 \%$ Vermicompost @ $3 \mathrm{t} / \mathrm{ha}, \mathrm{T}_{7}-50$ $\%$ RDF + $50 \%$ Rhizosphere Bacteria, $\mathrm{T}_{8}-25$ $\%$ RDF + 50 \% FYM @ 6 t/ha + $50 \%$ Vermicompost @ 3 t/ha, $\mathrm{T}_{9}-25 \% \mathrm{RDF}$ +50\% FYM @6t/ha + 50\% Vermicompost @ 3 t/ha $+50 \%$ Rhizosphere Bacteria. N, P and $\mathrm{K}$ were given through Urea, SSP and MOP respectively. Full dose of $\mathrm{P}$ and $\mathrm{K}$ and half dose of $\mathrm{N}$ were applied as basal dose, as per treatment before sowing and remaining half dose of $\mathrm{N}$ was given 30 days after sowing. Manures viz., FYM and vermicompost were incorporated as per treatment to respective plots prior to sowing. Biofertilizers (Azotobacter and PSB) were inoculated to seeds prior to sowing as seed treatment method. Seeds were sown at the spacing of $30 \times 5 \mathrm{~cm}$ and thinning was done 10 days after sowing to maintain spacing. The data were recorded on five plants per treatment per plot in each replication on growth and yield parameters. Observations were recorded on plant height, number of leaves per plant, leaf length, fresh weight of leaves time taken to first harvest, root length, root diameter, fresh weight of root, root yield per plot, root yield per hectare. The data were statistically analysed using analysis of variance (ANOVA) for RBD following the standard procedure as suggested by Panse and Sukhatme (1985). 


\section{Results and Discussion}

\section{Growth parameters}

Integrated nutrient management had significant effect on growth parameters of carrot (Table $1 \& 2$ ). Among the treatments, $\mathrm{T}_{9}$ treatment (25\% RDF + 50\% FYM @6 t/ha + 50\% Vermicompost @ 3 t/ha + 50\% Rhizosphere Bacteria) registered significantly higher plant height $(53.50 \mathrm{~cm})$, more number of leaves per plant (16.40), maximum leaf length $(38.20 \mathrm{~cm})$ and fresh weight of leaves $(62.46 \mathrm{~g})$ at harvest stage.

The maximum increase in plant height was due to readily availability of required quantities of nitrogen, which is being a constituent of amino acids, nucleotides, nucleic acids, a number of coenzymes, auxins, cytokinins and alkaloids, resulted in increased cell elongation, cell enlargement and cell division. Moreover the higher plant height could be due to certain growth promoting substances secreted by the biofertilizers i.e., Azotobacter and phosphate solubilizing bacteria, which in turn, might have led to better root development, better transportation of water, uptake and deposition of nutrients. The results are in accordance with the findings of Singh et al., (2017) and Kirad et al., (2010) in carrot.

More number of leaves per plant and maximum leaf length could be due to timely supply of all nutrients resulted in luxurious vegetative growth of plant. Moreover application of FYM and vermicompost helped in development of the physical, chemical and biological properties of soil which helps in better nutrient absorption and utilization by plant. Seed inoculation of biofertilizers might have helped to increase the biological nitrogen fixation and availability of phosphorous required for strong vegetative growth, ultimately led to production of more number of leaves per plant and maximum leaf length. Similar results were also reported by Singh et al., (2017), Kirad et al., (2010) and Vithwel Kanaujia (2013) in carrot.

Maximum fresh weight of leaves might be due to higher plant height, more number of leaves and maximum leaf area of this treatment as compared to the rest of treatments. The results are comparable with those of Singh et al., (2017), Kirad et al., (2010) in carrot and Khalid et al., (2015) in radish.

\section{Yield parameters}

The experimental results revealed that the yield parameters were significantly influenced by various treatments (Table 3 ). The mean number of days taken to harvest was found to be significant in all the treatments. Minimum number of days taken to harvest was recorded in $\mathrm{T}_{9}(25 \% \mathrm{RDF}+50 \% \mathrm{FYM} @ 6 \mathrm{t} / \mathrm{ha}+50$ $\%$ Vermicompost @ 3 t/ha + $50 \%$ Rhizosphere Bacteria) (75.33 days) and it was on par with $\mathrm{T}_{8}(25 \% \mathrm{RDF}+50 \% \mathrm{FYM} @ 6$ t/ha + 50\% Vermicompost @ 3 t/ha) (76.66 days). These results are due to the better plant growth, resulted in accelerated photosynthesis and translocation of photosynthates towards the root portion led to early physiological maturity rather than other treatments. The present investigation was inconsistent with the reports of Kushwah et al., (2016) in radish and Yogita et al., (2012) in onion.

Root length and diameter was found to be significantly different among all the treatments. Maximum root length and diameter $(19.76 \mathrm{~cm}$ and $3.96 \mathrm{~cm})$ were recorded under $\mathrm{T}_{9}(25 \% \mathrm{RDF}+50 \% \mathrm{FYM}$ @ $6 \mathrm{t} / \mathrm{ha}+50 \%$ Vermicompost @ $3 \mathrm{t} / \mathrm{ha}+50$ $\%$ Rhizosphere Bacteria) which was at par with $\mathrm{T}_{8}(25 \% \mathrm{RDF}+50 \%$ FYM @ 6 t/ha + $50 \%$ Vermicompost @ 3 t/ha). Higher vegetative growth under integrated 
application of nutrients might have helped in synthesis of greater amount of food materials which was later translocated into developing root resulting in increased root length and root diameter. Similarly maximum fresh weight of root $(81.33 \mathrm{~g})$ was also recorded under treatment $\mathrm{T}_{9}(25 \% \mathrm{RDF}+50 \% \mathrm{FYM} @ 6$ t/ha + 50\% Vermicompost @ 3 t/ha + 50\% Rhizosphere Bacteria) which was on par with $\mathrm{T}_{8}$. This might be due to higher root length and root diameter. These results are comparable with the reports of Vithwel Kanaujia (2013) in carrot and Khalid et al., (2015) in radish.

Table.1 Effect of integrated nutrient management on plant height $(\mathrm{cm})$ and number of leaves per plant at different growth stages of carrot cv. Kuroda improved

\begin{tabular}{|c|c|c|c|c|c|c|}
\hline \multirow[t]{2}{*}{ Treatment } & \multicolumn{3}{|c|}{ Plant height (cm) } & \multicolumn{3}{|c|}{ Number of leaves per plant } \\
\hline & 30 DAS & 60 DAS & At harvest & $30 \mathrm{DAS}$ & $60 \mathrm{DAS}$ & At harvest \\
\hline$T_{1}$ & $14.10^{\mathrm{c}}$ & $31.00^{\mathrm{c}}$ & $45.43^{\mathrm{c}}$ & $4.50^{\mathrm{c}}$ & $10.93^{\mathrm{c}}$ & $13.50^{\mathrm{c}}$ \\
\hline $\mathbf{T}_{2}$ & $10.00^{f}$ & $20.33^{f}$ & $28.00^{f}$ & $2.83^{f}$ & $5.80^{f}$ & $8.66^{f}$ \\
\hline $\mathbf{T}_{3}$ & $12.76^{d}$ & $24.83^{\mathrm{e}}$ & $35.00^{\mathrm{e}}$ & $3.23^{\mathrm{e}}$ & $7.93^{\mathrm{e}}$ & $10.33^{\mathrm{e}}$ \\
\hline $\mathbf{T}_{4}$ & $11.36^{\mathrm{e}}$ & $23.00^{\mathrm{e}}$ & $33.00^{\mathrm{e}}$ & $3.20^{\mathrm{e}}$ & $7.10^{\mathrm{e}}$ & $9.96^{\mathrm{e}}$ \\
\hline $\mathbf{T}_{5}$ & $13.26^{\mathrm{cd}}$ & $28.00^{d}$ & $39.33^{d}$ & $3.73^{\mathrm{d}}$ & $9.33^{d}$ & $11.86^{\mathrm{d}}$ \\
\hline $\mathbf{T}_{6}$ & $13.83^{\mathrm{cd}}$ & $28.40^{d}$ & $41.66^{\mathrm{d}}$ & $4.00^{d}$ & $9.63^{\mathrm{d}}$ & $12.16^{d}$ \\
\hline $\mathbf{T}_{7}$ & $13.60^{\mathrm{cd}}$ & $28.33^{d}$ & $40.00^{d}$ & $3.80^{d}$ & $9.60^{d}$ & $12.00^{\mathrm{d}}$ \\
\hline $\mathbf{T}_{8}$ & $15.60^{b}$ & $33.80^{b}$ & $49.56^{b}$ & $5.13^{b}$ & $12.33^{b}$ & $15.06^{b}$ \\
\hline$T_{9}$ & $17.06^{\mathrm{a}}$ & $36.66^{\mathrm{a}}$ & $53.50^{\mathrm{a}}$ & $5.83^{\mathrm{a}}$ & $13.83^{a}$ & $16.40^{\mathrm{a}}$ \\
\hline CD at $5 \%$ & 1.31 & 2.55 & 3.68 & 0.47 & 1.26 & 1.20 \\
\hline SEm \pm & 0.43 & 0.85 & 1.22 & 0.15 & 0.42 & 0.4 \\
\hline
\end{tabular}

Note: $\mathrm{T}_{1}$ - RDF (NPK @ 50:40:50 kg/ha), $\mathrm{T}_{2}$ - FYM 12 t/ha, $\mathrm{T}_{3}$ - Vermicompost @ 6 t/ha, $\mathrm{T}_{4}$ - Rhizosphere Bacteria (AZB + PSB each @ $7 \mathrm{~kg} / \mathrm{ha}$ ), $\mathrm{T}_{5}-50 \% \mathrm{RDF}+50 \% \mathrm{FYM} @ 6 \mathrm{t} / \mathrm{ha}, \mathrm{T}_{6}-50 \% \mathrm{RDF}+50 \%$ Vermicompost @ 3 $\mathrm{t} / \mathrm{ha}, \mathrm{T}_{7}-50 \% \mathrm{RDF}+50 \%$ Rhizosphere Bacteria, $\mathrm{T}_{8}-25 \% \mathrm{RDF}+50 \% \mathrm{FYM} @ 6 \mathrm{t} / \mathrm{ha}+50 \%$ Vermicompos @ 3 t/ha, $\mathrm{T}_{9}-25 \% \mathrm{RDF}+50 \%$ FYM @ 6 t/ha + 50\% Vermicompost @ 3 t/ha + 50\% Rhizosphere Bacteria.

Table.2 Effect of integrated nutrient management on leaf length $(\mathrm{cm})$ and fresh weight of leaves (g) at different growth stages of carrot cv. Kuroda improved

\begin{tabular}{|c|c|c|c|c|c|c|}
\hline \multirow[t]{2}{*}{ Treatment } & \multicolumn{3}{|c|}{ Leaf length $(\mathrm{cm})$} & \multicolumn{3}{|c|}{ Fresh weight of leaves (g) } \\
\hline & 30 DAS & $60 \mathrm{DAS}$ & At harvest & $30 \mathrm{DAS}$ & 60 DAS & At harvest \\
\hline $\mathbf{T}_{1}$ & $8.16^{c}$ & $22.06^{\mathrm{c}}$ & $32.36^{\mathrm{c}}$ & $4.53^{\mathrm{c}}$ & $40.20^{b}$ & $51.66^{b}$ \\
\hline $\mathbf{T}_{2}$ & $5.06^{f}$ & $12.66^{f}$ & $19.63^{f}$ & $2.00^{f}$ & $24.00^{f}$ & $34.57^{\mathrm{e}}$ \\
\hline $\mathbf{T}_{3}$ & $6.23^{\mathrm{e}}$ & $17.90^{\mathrm{e}}$ & $25.00^{\mathrm{e}}$ & $2.87^{\mathrm{e}}$ & $28.20^{\mathrm{e}}$ & $39.00^{d}$ \\
\hline $\mathbf{T}_{4}$ & $5.60^{\text {ef }}$ & $16.00^{\mathrm{e}}$ & $22.66^{\mathrm{e}}$ & $2.57^{\text {ef }}$ & $27.73^{\mathrm{e}}$ & $38.56^{\text {de }}$ \\
\hline $\mathbf{T}_{5}$ & $7.16^{d}$ & $19.86^{\mathrm{d}}$ & $28.66^{d}$ & $3.63^{d}$ & $32.66^{d}$ & $43.33^{\mathrm{c}}$ \\
\hline$T_{6}$ & $7.30^{\mathrm{cd}}$ & $20.13^{d}$ & $29.40^{d}$ & $3.90^{d}$ & $36.00^{c}$ & $45.00^{\mathrm{c}}$ \\
\hline $\mathbf{T}_{7}$ & $7.20^{d}$ & $20.00^{d}$ & $29.00^{d}$ & $3.73^{d}$ & $34.66^{\mathrm{cd}}$ & $44.66^{\mathrm{c}}$ \\
\hline $\mathbf{T}_{8}$ & $9.60^{b}$ & $24.00^{b}$ & $35.33^{b}$ & $5.13^{b}$ & $43.66^{\mathrm{a}}$ & $58.00^{\mathrm{a}}$ \\
\hline$T_{9}$ & $11.03^{\mathrm{a}}$ & $26.63^{\mathrm{a}}$ & $38.20^{\mathrm{a}}$ & $5.86^{a}$ & $46.50^{\mathrm{a}}$ & $62.46^{\mathrm{a}}$ \\
\hline CD at $5 \%$ & 0.92 & 1.92 & 2.84 & 0.57 & 3.26 & 4.19 \\
\hline SEm \pm & 0.30 & 0.64 & 0.94 & 0.19 & 1.08 & 1.39 \\
\hline
\end{tabular}

Note: $\mathrm{T}_{1}$ - RDF (NPK @ 50:40:50 kg/ha), $\mathrm{T}_{2}$ - FYM $12 \mathrm{t} / \mathrm{ha}, \mathrm{T}_{3}$ - Vermicompost @ $6 \mathrm{t} / \mathrm{ha}, \mathrm{T}_{4}-$ Rhizosphere Bacteria (AZB + PSB each @ $7 \mathrm{~kg} / \mathrm{ha}$ ), $\mathrm{T}_{5}-50 \% \mathrm{RDF}+50 \% \mathrm{FYM} @ 6 \mathrm{t} / \mathrm{ha}, \mathrm{T}_{6}-50 \% \mathrm{RDF}+50 \%$ Vermicompost @ 3 $\mathrm{t} / \mathrm{ha}, \mathrm{T}_{7}-50 \% \mathrm{RDF}+50 \%$ Rhizosphere Bacteria, $\mathrm{T}_{8}-25 \% \mathrm{RDF}+50 \% \mathrm{FYM} @ 6 \mathrm{t} / \mathrm{ha}+50 \%$ Vermicompos @ 3 t/ha, $\mathrm{T}_{9}-25 \% \mathrm{RDF}+50 \%$ FYM @ $6 \mathrm{t} / \mathrm{ha}+50 \%$ Vermicompost @ $3 \mathrm{t} / \mathrm{ha}+50 \%$ Rhizosphere Bacteria. 
Table.3 Effect of INM on yield parameters of carrot cv. Kuroda improved

\begin{tabular}{|c|c|c|c|c|c|c|}
\hline Treatment & $\begin{array}{c}\text { Time taken } \\
\text { to first } \\
\text { harvest } \\
\text { (days) }\end{array}$ & $\begin{array}{l}\text { Root length } \\
\text { (cm) }\end{array}$ & $\begin{array}{c}\text { Root } \\
\text { diameter } \\
\text { (cm) }\end{array}$ & $\begin{array}{c}\text { Fresh } \\
\text { weight of } \\
\text { root }(g)\end{array}$ & $\begin{array}{c}\text { Root yield } \\
\text { (kg/plot) }\end{array}$ & $\begin{array}{c}\text { Root yield } \\
\text { (t/ha) }\end{array}$ \\
\hline $\mathbf{T}_{1}$ & $79.33^{b}$ & $17.50^{b}$ & $3.73^{a}$ & $74.23^{b}$ & $4.33^{\mathrm{c}}$ & $14.43^{c}$ \\
\hline $\mathbf{T}_{2}$ & $87.00^{\mathrm{e}}$ & $12.17^{\mathrm{e}}$ & $2.23^{d}$ & $44.33^{\mathrm{e}}$ & $2.26^{\mathrm{f}}$ & $7.53^{f}$ \\
\hline$T_{3}$ & $85.33^{\mathrm{e}}$ & $14.00^{d}$ & $2.66^{c}$ & $53.33^{d}$ & $2.83^{\mathrm{e}}$ & $9.43^{\mathrm{e}}$ \\
\hline $\mathbf{T}_{4}$ & $86.66^{e}$ & $13.66^{d}$ & $2.73^{\mathrm{c}}$ & $49.66^{\mathrm{de}}$ & $2.63^{\text {ef }}$ & $8.76^{\text {ef }}$ \\
\hline $\mathbf{T}_{5}$ & $83.33^{d}$ & $15.66^{c}$ & $3.16^{b}$ & $62.66^{c}$ & $3.60^{d}$ & $12.00^{d}$ \\
\hline$T_{6}$ & $81.33^{\mathrm{c}}$ & $15.80^{\mathrm{c}}$ & $3.26^{b}$ & $67.73^{c}$ & $3.80^{\mathrm{d}}$ & $12.66^{d}$ \\
\hline $\mathbf{T}_{7}$ & $83.00^{\mathrm{cd}}$ & $15.73^{c}$ & $3.20^{b}$ & $64.33^{c}$ & $3.70^{d}$ & $12.33^{d}$ \\
\hline $\mathbf{T}_{8}$ & $76.66^{a}$ & $18.33^{\mathrm{ab}}$ & $3.80^{\mathrm{a}}$ & $78.00^{a b}$ & $4.96^{b}$ & $16.53^{b}$ \\
\hline$T_{9}$ & $75.33^{a}$ & $19.76^{a}$ & $3.96^{\mathrm{a}}$ & $81.33^{\mathrm{a}}$ & $5.60^{\mathrm{a}}$ & $18.60^{\mathrm{a}}$ \\
\hline CD at $5 \%$ & 1.98 & 1.48 & 0.37 & 6.32 & 0.47 & 1.40 \\
\hline SEm \pm & 0.66 & 0.49 & 0.12 & 2.10 & 0.15 & 0.46 \\
\hline
\end{tabular}

Note: $\mathrm{T}_{1}$ - RDF (NPK @ 50:40:50 kg/ha), $\mathrm{T}_{2}$ - FYM $12 \mathrm{t} / \mathrm{ha}, \mathrm{T}_{3}$ - Vermicompost @ $6 \mathrm{t} / \mathrm{ha}, \mathrm{T}_{4}$ - Rhizosphere Bacteria (AZB + PSB each @ $7 \mathrm{~kg} / \mathrm{ha}$ ), $\mathrm{T}_{5}-50 \% \mathrm{RDF}+50 \% \mathrm{FYM} @ 6 \mathrm{t} / \mathrm{ha}, \mathrm{T}_{6}-50 \% \mathrm{RDF}+50 \%$ Vermicompost @ 3 $\mathrm{t} / \mathrm{ha}, \mathrm{T}_{7}-50 \% \mathrm{RDF}+50 \%$ Rhizosphere Bacteria, $\mathrm{T}_{8}-25 \% \mathrm{RDF}+50 \% \mathrm{FYM} @ 6 \mathrm{t} / \mathrm{ha}+50 \%$ Vermicompos @ 3 t/ha, $\mathrm{T}_{9}-25 \% \mathrm{RDF}+50 \%$ FYM @ $6 \mathrm{t} / \mathrm{ha}+50 \%$ Vermicompost @ 3 t/ha + 50\% Rhizosphere Bacteria.

Significant difference observed among the treatments with respect to root yield per plot and yield per hectare. Among the treatments, $\mathrm{T}_{9}(25 \% \mathrm{RDF}+50 \% \mathrm{FYM} @ 6 \mathrm{t} / \mathrm{ha}+50 \%$ Vermicompost@3t/ha +50\% Rhizosphere Bacteria) reported significantly maximum root yield per plot and yield per hectare (5.60 $\mathrm{kg}$ and $18.60 \mathrm{t} / \mathrm{ha}$ respectively). These results are due to the maximum fresh weight of root of this treatment as compared to rest of the treatments. These findings are in line with the reports of Singh et al., (2017), Kirad et al., (2010), Vithwel Kanaujia (2013) in carrot and Khalid et al., (2015) in radish.

\section{References}

Ahmad, B., Bakhsh, K. and Hassan, S. 2004. Economics of growing carrot, Faculty of Agricultural Economics and R.S., University of Agriculture, Faisalabad. A report submitted to Pakistan Agricultural Research Council (PARC), Islamabad, Pakistan.

Amjad, M., Naz, S. and Ali, S. 2005. Growth and seed yield of carrot as influenced by different regimes of nitrogen and potassium. J. Res. Sci. 16 (2): 73-78.

Handelman. G.J. 2001. The evolving role of carotenoids in human biochemistry. Nutrition, 17:818-822.

Khalid, M., Yadav, M.P., Amar, S. and Yadav, B.K. 2015. Studies on the effect of Integrated nutrient management on growth and yield attributing characters of radish (Raphanus sativus L.). Annals of Horticulture. 8(1):81-83.

Kirad, K. S., Barch, S. and Singh, D. B. 2010. Integrated nutrient management on growth, yield and quality of carrot. Karnataka J. Agric. Sci. 23 (3): 542-543

Kushwah. L. 2016. Effect of organic manures, inorganic fertilizers and their combinations on growth, yield and quality of radish (Raphanus sativus L.). M.Sc. (Horti.). Thesis submitted to RVSKVV, Mandsaur (M.P.)

Panse, V. G. and Sukhatme, P. V. 1967. Statistical methods for Agricultural workers. Indian Council of Agricultural Research, New Delhi.

Rossi, P. G., Bao, L., Luciani, A., Panighi, J., 
Desjober, J. M., Bolla, J. J. and Berti, L. 2007. E-methylisoeugenol and elemicin: antibacterial components of Daucus carota L. essential oil against Campylobacter jejuni. Journal of Agricultual and Food Chemistry. 55:7332-7336.

Singh, D. P., Kumar, S., Sutanu, M. and Vijay, P. K. 2017. Studies on integrated nutrient management on growth, yield and quality of carrot (Daucus carota L.). International Journal of Agriculture Sciences. 51(8): 2187-2188.

Sunandarani, N., Mallareddy, K. 2007. Effect of different organic manures and inorganic fertilizers on growth, yield and quality of carrot (Daucus carota L.). Karnataka Journal of Agricultural Sciences. 20 (3): 686-688.

Vithwel Kanaujia, S.P. 2013. Integrated nutrient management on productivity of carrot and fertility of soil. SAARC Journal of Agriculture. 11 (2): 173-181.

Yogita, Ram, R. B. and Babu, M. 2012. Effect of inorganic and biofertilizers on growth and yield of onion (Allium cepa L.) cv. Pusa Madhavi. Plant Archives. 12(2): 645-648.

\section{How to cite this article:}

Shanu, V., D. Lakshminarayana, P. Prasanth and Saida Naik, D. 2019. Studies on the Effect of Integrated Nutrient Management (INM) on Growth and Yield Parameters of Carrot (Daucas carota L.) cv. Kuroda Improved under Southern Telangana Conditions. Int.J.Curr.Microbiol.App.Sci. 8(04): 2786-2791. doi: https://doi.org/10.20546/ijcmas.2019.804.324 